\title{
Ecotourism Attractions, Level of Satisfaction and Management of Air Terjun Kembar in Kampung Anyar Village, Banyuwangi
}

\author{
Alfian, Febi Wahyu Sulistyadi ${ }^{*}$, Pratama Diffi Samuel, Emanuel Naitio \\ Master Program of Environmental Resources Management and Development, Graduate Program, University of \\ Brawijaya, Malang, Indonesia
}

\section{Abstract}

Air Terjun Kembar (Twin Waterfall) in Kampung Anyar, Banyuwangi is an alternative tourist travel destinations around the ljen crater. This study aims to determine the history, attractions, eco-tourism potential, the level of customer satisfaction and further management for the area. The method is carried out by semi-structured interviews, questionnaires based on the satisfaction level of Sapta Pesona (standard value) and SWOT Analysis to the management. These results indicate that previously Kembar Waterfall Kampung Anyar was used for water resources. Then, in 2014 began to be managed by the group of people in Kampung Anyar. SWOT analysis shows that the management is good. In some aspect however it needs to be improved.

Keywords: Ecotourism, Kampung Anyar, Sapta Pesona, SWOT.

\section{INTRODUCTION}

Banyuwangi is the most eastern region that was in the area of East Java which is now better known as Sunrise of Java. Banyuwangi Regency now been established as tourist areas by the local government. The most famous attractions in Banyuwangi are tour to ljen crater, the Red Island, and G-Land. However, there are several tourist attractions located around these tourist attractions. Travel to ljen Crater which is located around Glagah districts, there are several natural attractions which is quite interesting. One of them is located in the village of Kampung Anyar, namely the Air Terjun Kembar (Twin Waterfall). Air Terjun Kembar tourism has recently been managed by local people using village funds and assistance from the local government. Air Terjun Kembar Tourism in Kampung Anyar saves one potential that is quite interesting. Moreover, if it dealt seriously, then it would make this area into a tourist destination alternative to the ljen crater. Tourism management will be better again, if ecotourism being developed. Ecotourism is nature tourism with mild impact which causes the maintenance of species and their habitat direct role in the preservation and indirectly by providing local public view, to make the local community to put value, and protect nature and other lifes as revenue sources [1]. Meanwhile, according to the Regulation of the Domestic Minister No. 33 of 2009 on Guidelines for

\footnotetext{
* Correspondence address: Febi Wahyu Sulistyadi

Email : febjoki@gmail.com

Address : Jl. Mayjen Haryono No. 169, 65145 Malang.
}

Ecotourism Development in the Region, Ecotourism is nature tourism activities in the area of responsibility with regard elements of education, understanding, and support for the efforts of conservation of natural resources, as well as increased income of local communities. In concept of ecotourism, it can be defined as a concept of sustainable tourism development which aims to support the efforts of environmental conservation (nature and culture) and increase public participation in the management, so that economic beneficially for the local community [2].

Air Terjun Kembar in Kampung Anyar is administratively located in District of Glagah, Banyuwangi. It is one of the new tourist areas that are on the road to ljen Creater Tourism. This tour is managed by the local community by establishing a community. Previously, the Waterfall is a place for people to obtain water. Around 2014, group of residents tried to repair the access road and also build infrastructure. Thus, it serves additional tours for traveler from ljen Creater Tourism. Air Terjun Kembar in Kampung Anyar is not charge for admission, so that in the holiday it becomes one of the excellent low budget tours in the area. Meanwhile, the community obtains benefit from vehicle parking tickets, water cleanliness of the toilets and also from trade in Air Terjun Kembar tour of Kampung Anyar. In addition to the Kembar Waterfall, there is another waterfall which is called the Air Terjun Tunggal (Single Waterfall).

Air Terjun Kembar Tourism in Kampung Anyar needs to be well and sustainably managed. This 
study aims to determine the history, attractions, eco-tourism potential, the level of customer satisfaction and further management.

\section{MATERIALS AND METHODS}

This research was conducted on October 2015 at Air Terjun Kembar in Kampung Anyar Village, District of Glagah, Banyuwangi (Fig. 1).

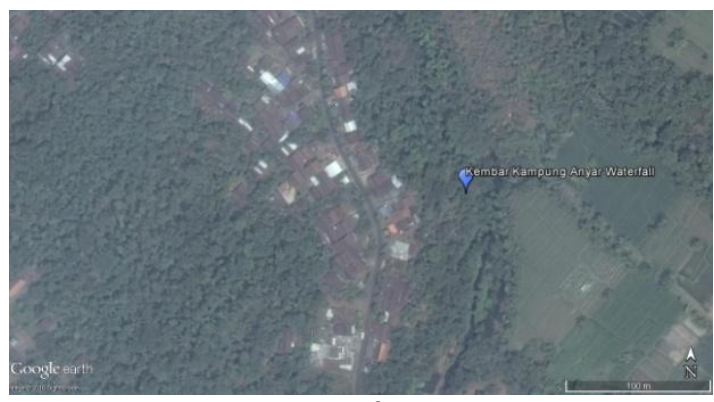

Figure 1. Location of Kampung Anyar

\section{Field Observation}

Field observation was carried out through tourism potential object in area of Air Terjun Kembar. Potential object for tourism was listed and descriptive characteritisc of object was drawn. In order to generate comprehensive information regarding tourist object, an indepth interviews with key person in water fall area was implemented. Focus of the intervews was the histrory of the discovery of Air Terjun Kembar as tourist object and effort to convert and promotes waterfall as tourist attraction.

\section{Questionnaire on Tourist Satisfaction}

The quisionare was distribute to the 30 tourist who visit Air Terjun Kembar. Respondents selection is done randomly. The quisioner components in question is constructed based on the Sapta Pesona. Sapta Pesona is a concept that is issued by the Ministry of Tourism and Creative Economy. Sapta Pesona is seven elements of the charm that must be realized for the creation of a conducive environment and ideal for the development of tourism activities in a place that encourage tourists to visit [3]. Sapta Pesona has seven aspects: security, order, cleanliness, coolness, beauty, friendliness, and impression. The results will be analyzed in Microsoft Excel and seen the percentage level of satisfaction.

\section{SWOT Analysis}

SWOT analysis is the analysis conducted on four things: Strengh, Weakness, Oportunity and Threath. SWOT analysis is used Management to ecotourism resource relationships with other resources [5]. The purpose of the SWOT analysis in this study is to determine the strategy that should be adopted for the development of Air Terjun Kembar attraction. The assessment of each case can be determined on quadrant of SWOT analysis (Table 1). Furthermore, it can be seen in terms of the development on the tourist attraction.

Table 1. Quadrant SWOT Analysis

\begin{tabular}{lcc}
\hline External/Internal & Strength & Weaknes \\
\hline Opportunities & $\mathrm{O}-\mathrm{S}$ & $0-\mathrm{W}$ \\
Threat & $\mathrm{T}-\mathrm{S}$ & $\mathrm{T}-\mathrm{W}$ \\
\hline
\end{tabular}

\section{RESULT AND DISCUSSION}

\section{History of Air Terjun Kembar}

There are many waterfall in Banyuwangi, some of them located in the location that is quite hidden and challenging. One of the Waterfall that is still fairly new known and has relatively easy access is a waterfall located in the Kampung Anyar villages, District of Glagah, Banyuwangi. Three waterfalls are located in one location and the position are very closely together, so that some called it as the Air Terjun Kembar or Air Terjun Jagir or Air Terjun Kampung Anyar. Initially this waterfall enabled residents to the water source, and then in 2014, a community built access roads, toilets and food stalls to be used as tourist attractions [6].

This Kampung Anyar Village Waterfall comes from three springs that appear on top of a cliff, i.e. springs of Jagir, Pawon and Buyut ljah. The most interesting Waterfall here is the springs of Pawon, because the water flowing is not too heavy and fairly wide. The atmosphere is cool scent of mountains give coolness to the end that came to the place. While enjoy the view of the waterfall, tourist can play/shower under the waterfall and takes pictures of stream. Near to the two waterfalls, located about $200 \mathrm{~m}$ west there is Kategan Waterfall. To get to the Kategan Waterfall, tourists can follow the river as far as $100 \mathrm{~m}$ upstream. Kategan Waterfall derived from waterfall sources that falls to Kalibendo. This waterfall is higher than the two previous waterfalls and had a fairly heavy flow of water [7].

Access to this area is easy, takes only 20 minutes from downtown Banyuwangi westward to the Kampung Anyar Village about $15 \mathrm{~km}$. The tourist area around the waterfall reserved parking areas are mostly located in front of houses and stalls set up by locals. From the parking area, tourist need to walk down the cliff 
for $100 \mathrm{~m}$, on the middle of the trip we will meet a very beautiful view of the cliff, with pieces of rock that sticks like a shiny diamond carved chunks if exposed by water runoff [8].

\section{Ecotourism Attractions}

Air Terjun Kembar is the potential ecotourism attractions. Air Terjun Kembar itself is derived from the flow of the river in the village of Kampung Anyar. A pool was built at the bottom of Kembar Waterfall, constructed by a group of local people. The pool can be used for bathing and swimming by tourist. Around the waterfall, there is also toilets and food stalls which is managed by goverment (PDAM-Local Water Company).

Beside the Air Terjun Kembar, there is one more ecotourism attraction in the area, namely Air Terjun Tunggal (Fig. 2), which is at the north side of Air Terjun Kembar. For passing this Air Terjun Tunggal, tourists can tracking passed the river. Around the river tourists are also treated by the view of plantation residents. To go to Air Terjun Tunggal, travelers from the entrance immediately turn to the left, while the right side is Air Terjun Kembar. Pathway to Air Terjun Tunggal traversed by walking on the riverbank. After walked about 10-15 minutes, the visitors would have reached the Air Terjun Tunggal. In Air Terjun Tunggal tourists can see the waterfall with a height of about $50 \mathrm{~m}$. However, there is no facilities in Air Terjun Tunggal, conversely to facilities (toilets and food stalls) in Air Terjun Kembar (Fig.3).

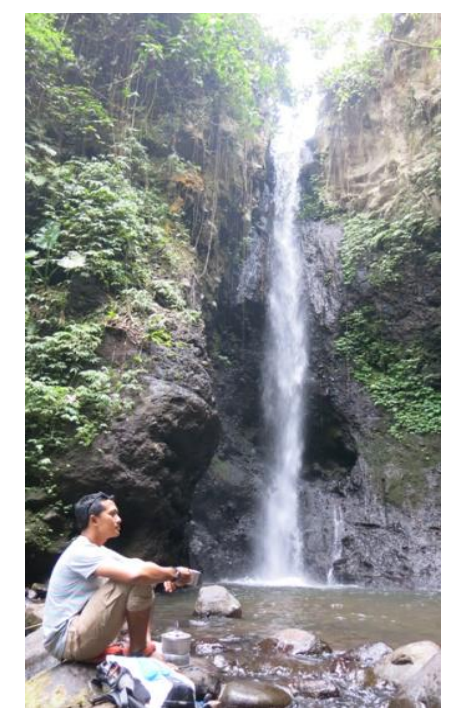

Figure 2. Air Terjun Tunggal

\section{Ecotourism Potential of Air Terjun Kembar}

The waterfalls in Kampung Anyar Village are specially located because visitors will be able to enjoy three Waterfall at once in one place, Air Terjun Kembar. About $20 \mathrm{~m}$ from the Air Terjun Kembar, there is another Air Terjun Tunggal, although it is not as beautiful as the Air Terjun Kembar because there are buildings on the top of it and there was washing spills from the residents or the local community. However, as a whole, it still does not detract the beauty of the waterfall (Fig.4). In addition, there is also a waterfall as local people called, the Kategan Waterfall which is located about $\mathbf{3 0 0}$ me to the west. It is also as exotic as Air Terjun Kembar because it falls comes from Kalibendo streams instead of the spring so that the water discharge more rapidly than Air Terjun Kembar. To go to the location of the waterfall, there is relatively difficult road that must be passed because through down shrubs, trees and river flow. However, visitors should not be worry because it does not need to take a long time to reach the location.

Besides the beauty of the waterfall, the potential objects which can still be enjoyed in the village is a slope of $90^{\circ}$ cliff that has a unique shape. Prism protrusions are resembling stone diamond flakes. This cliff is quite interesting for extreme sports enthusiasts because of its very challenging height given by the slope of the cliff to reach $90^{\circ}$.

Air Terjun Kembar is located not far from the plantation of Kalibendo. Perhaps many people have passed but was not aware of its existence. Location of the waterfall is approximately $1 \mathrm{~km}$ east of Kalibendo. In addition to the road conditions are good, the location is also located on the edge of the road makes it easy to reach. Once entering the village we will be faced with a view of trees and farm/ricefield right way. Bounded by cliffs which beneath is clear water river. Among the cliff, there are three Waterfall that were located very close together.

\section{Tourist Satisfaction Level}

Waterfall tourist visitors of Air Terjun Kembar in Kampung Anyar are 55\% female and $45 \%$ male, with majority of $>50 \%$ visitors are high school students (Fig.5). The results of questionnaires shown that the level of satisfaction of each factor is fairly high. This can be seen in the table that the satisfaction level of each factor is over $50 \%$ (Table 2). Thus it can be said that Air Terjun Kembar tour visitors satisfied on the existed attractions. 


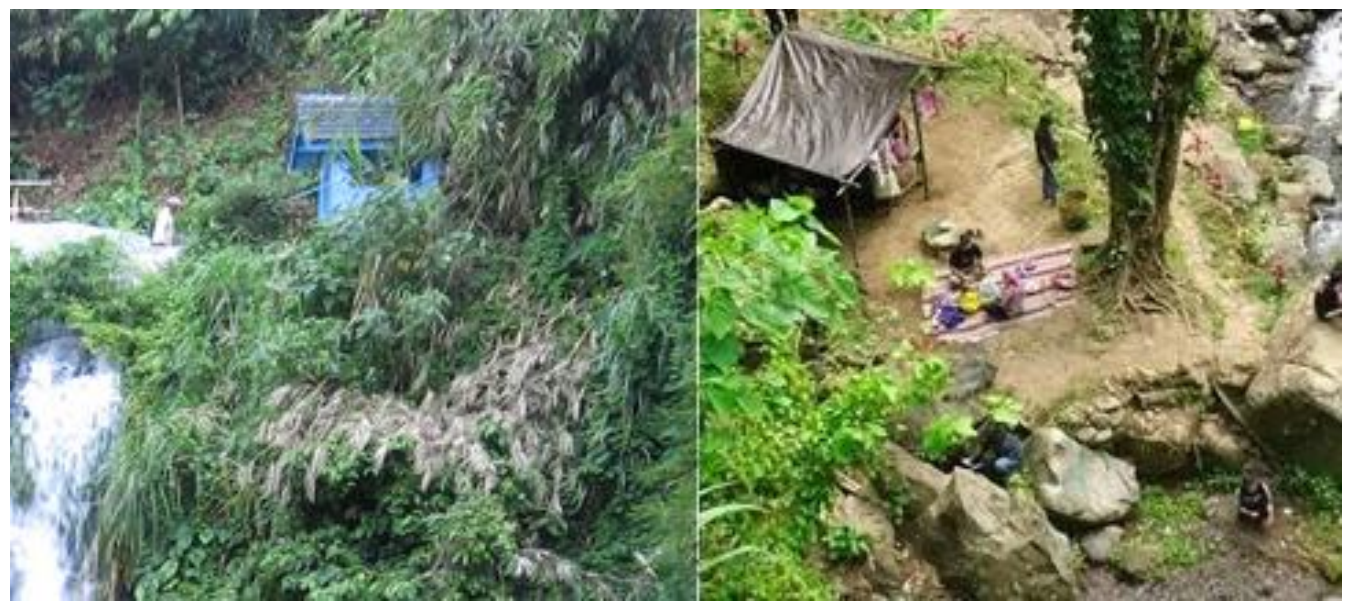

Figure 3. Facilities at Air Terjun Kembar (stalls and toilets)

Table 2. Tourist Satisfaction Level Based on Sapta Pesona

\begin{tabular}{lc}
\hline Sapta Pesona & Satisfaction Level (\%) \\
\hline Security & 61.16 \\
Order & 60.48 \\
Cleanliness & 64.52 \\
Coolness & 78.45 \\
Beauty & 66.94 \\
Friendliness & 67.30 \\
Impression & 66.24 \\
\hline
\end{tabular}

While the coolness factor has the highest satisfaction level of $78.45 \%$. The environment is still beautiful and yet so much potential for the development of the area. In addition, the location of the waterfall at the foothills of Mount Ijen adds the atmosphere of coolness. While the order is a lowest factor level of satisfaction for $60.48 \%$. This could be due to the lack of personnel in the sights. In addition, there is no admission charges that makes this attraction has no significant revenues yet, thus the order becomes less. Because, if there is admission and significant revenues from the attraction, the funds could be used to pay officers so that order can be well improved.

\section{SWOT Analysis}

Assessment of SWOT analysis was performed on each of these factors (Table 3). Thus obtained quadrant SWOT analysis ( Fig.6) than can be used to plan appropriate strategies for the Ecotourism development in Air Terjun Kembar in Kampung Anyar [9]. The suitable strategies for this ecotourism development determine in quadrants based on the analysis.

The location of the strategy quadrant is in first quadrant (Fig.6), which means that the strategy in the management of Air Terjun Kembar travel is appropriate. However, it should be improved further to attract more visitors. Especially in the field of cleanliness, such as less trash on the road to the Air Terjun Tunggal.

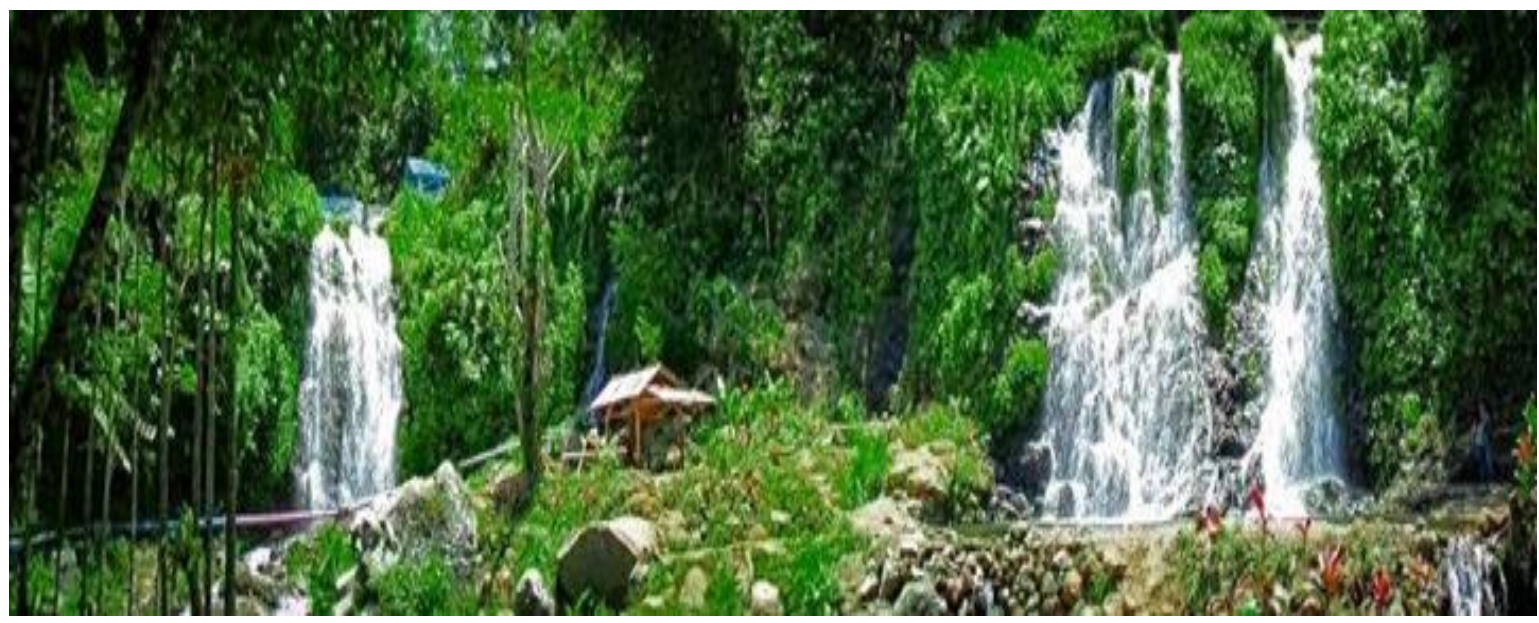

Figure 4. Air Terjun Kembar, Kampung Anyar Village 

(Alfian et al.)

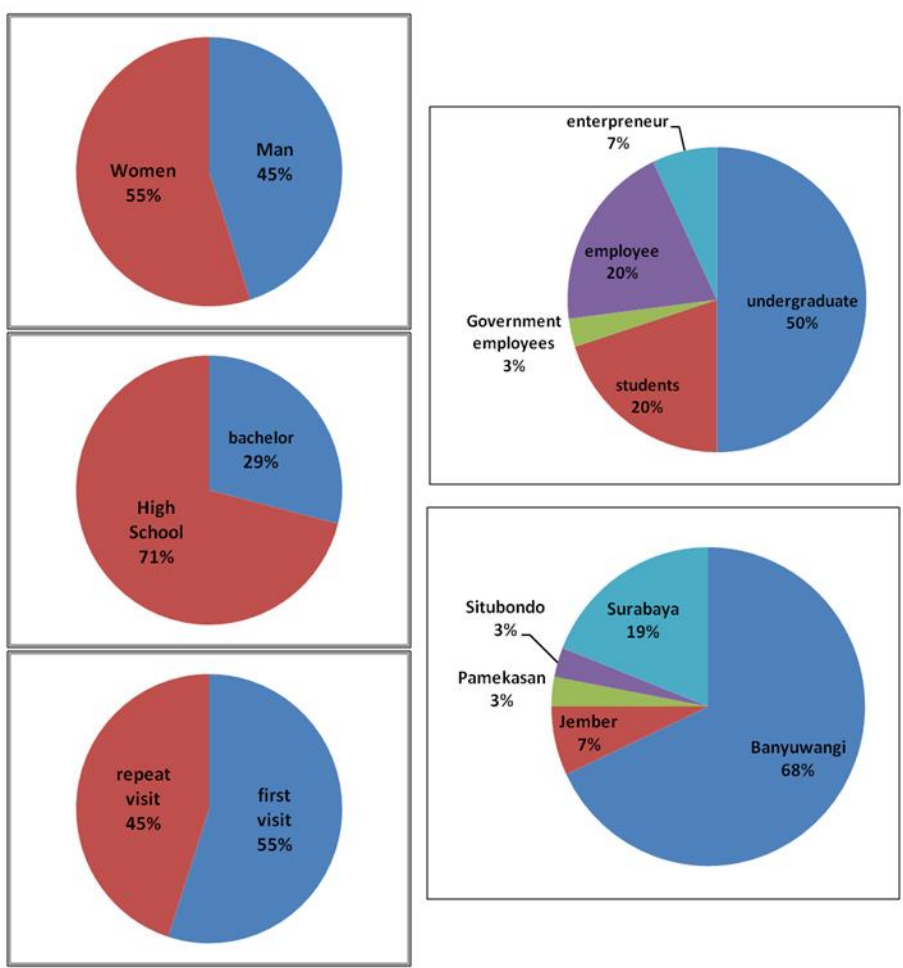

Figure 5. Chart of Data Visitor in Air Terjun Kembar

Table 3. SWOT Analysis

\begin{tabular}{ll}
\hline Strengths $(\mathbf{S})$ & Weaknesses $(\mathbf{W})$ \\
Environment unspoiled & Facilities and infrastructure are inadequate \\
Attractive waterfall & Garbage is strewn \\
There is a natural swimming pool & Lack of personnel in the tourist area \\
Local people are friendly to visitors & The lack of promotion of tourist areas \\
\hline $\begin{array}{l}\text { Opportunities (O) } \\
\text { Adjacent to the tourist area of the ljen Crater }\end{array}$ & Threat (T) \\
$\begin{array}{l}\text { As one of the alternative tourist destination } \\
\text { Support from local government }\end{array}$ & Many visitors on certain days \\
The management is independent by the local community & Some people have not been involved in the management \\
\hline
\end{tabular}

\begin{tabular}{c|c} 
& $\begin{array}{c}\text { Opportunities } \\
\text { Quadrant II }\end{array}$ \\
& $\begin{array}{c}0.15 ; 0.38 \\
\text { Weakness }\end{array}$ \\
Quadrant III & Quadrant IV \\
Threat &
\end{tabular}

Figure 6. Quadrant of SWOT Analysis

\section{CONCLUSION}

Air Terjun Kembar was first functionalized as a resource of water, then in 2014 managed by community and used as tourist attractions. Most of the visitors are students. The highest satisfaction levels of visitors is the coolness factor, while order is being the lowest factor. Attractions offered is parallel Waterfall so-called Air Terjun Kembar, plus Air Terjun Tunggal that can be accessed by tracking. The potential of the access to the Air Terjun Tunggal needs to be improved, especially in the presence of trash and roads need to be built. Based on the SWOT analysis, management of Air Terjun Kembar are fairly good however needs to be improved, especially on the access to the Air Terjun Tunggal. 


\section{REFERENCES}

[1] Goodwin, H. J., I. J. Kent, K. T. Parker and M. J. Walpole. 1997. Tourism, conservation and sustainable development Vol I. Unpublished.

[2] Hadinoto. 1997. Perencanaan pengembangan destinasi pariwisata. Gramedia. Jakarta.

[3] Ministry of Tourism and Creative Economy. 2012. Buku pedoman kelompok sadar wisata. Ministry of Tourism. Jakarta.

[4] Moleong, L. J. 2005. Metodologi penelitian kualitatif. Remaja Rosdakarya. Bandung.

[5] Damanik, J. and H. F. Weber. 2006. Perencanaan ekowisata: dari teori ke aplikasi. Tourism Center of Gadjah Mada University and Andi Publisher. Yogyakarta.

[6] Banyuwangibagus. 2014. Air terjun Three in One Kampung Anyar. Available at: http://www.banyuwangibagus.com/2014/0 9/air-terjun-three-in-one-kampung-anyar. html.

[7] Budi, K. 2015. Segarnya Air Terjun Kembar Kampung Anyar. Avaliable at: http://travel. kompas.com/read/2015/03/31/082117427/ Segarnya.Air.Terjun.Kembar.KampungAnyar

[8] Banyuwangitourism, 2015. Air Terjun Kampung Anyar. Available at: http://banyu wangitourism.com/content/air-terjunkampung-anyar.

[9] Statistic Center. 2014. Analisis SWOT. Available at: daps.bps.go.id/file_artikel/66/ Analisis\%20SWOT.pdf. 